\title{
Territories in Dispute: Tensions between 'Extractivism', Ethnic Rights, Local Governments and the Environment in Bolivia, Colombia, Ecuador and Peru
}

\author{
Darío Indalecio Restrepo Botero and Camilo Andrés Peña Galeano
}

\begin{abstract}
This chapter studies the underlying tensions between 'extractivism', decentralisation processes, the recognition of ethnic rights, and the protection of the environment in four countries in Latin America. Two of them, Bolivia and Ecuador, adhere to so-called twenty-first century socialism, while the other two, Colombia and Peru, apply policies driven by neo-liberalism. This 'major ideological fissure', however, does not imply significant differences in terms of dependence on the extractives industry and its social, institutional and political consequences; nor does it explain differences in terms of the relationships between extractivism, decentralisation, and the governments' policies concerning the environment and ethnic rights.
\end{abstract}

In the 1980s, Latin American countries initiated the process of dismantling state-led import substitution industrialisation strategies, to replace them with globalisation approaches that aimed to drive internal markets, privatise large assets and state monopolies, deregulate the private sector, and take various measures to make labour markets more flexible (Zabalo and Zurbano, 2011).

The adoption of neo-liberal systems led to a deepening of 'structural heterogeneity', which caused their economies to move in two circuits: the first driven by the competitive and modern sectors of the economy, the second pushed along by sectors that lack the technology needed to compete abroad ${ }^{1}$

1 A given industry may or may not be situated entirely in one circuit. For example, hydrocarbons tend to be situated in the 'modern' sector, which is characterised by high technology, capital and links to the global market; by comparison, clothing production overlaps both

(C) RESTREPO BOTERO AND PEÑA GALEANO, 2017 | DOI 10.1163/9789004351677_013

This is an open access chapter distributed under the terms of the CC-BY-NC License. 


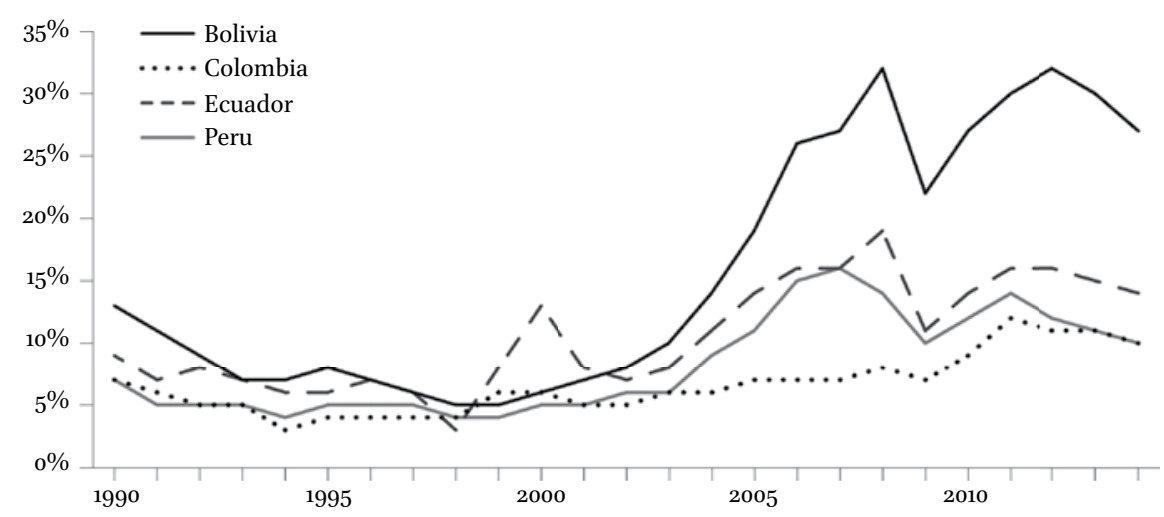

FIGURE 12.1 Exports from energetic mining extractivism as a percentage of GDP, 1990-2014. SOURCE: AUTHORS, WITH DATA FROM UN COMTRADE AND THE WORLD BANK.

(Sánchez, 2006). Consequently, countries sacrifice industrial capacity as they progressively increase their dependence on raw material exports. In this context, both the vulnerability and internal volatility of the economies grow since they are exposed to volatility in international prices for raw materials and in global demand. At the same time, emerging economies are subordinated to an international division of labour by which they export large quantities of natural resources and import high added-value manufactured goods. This deepens technological and financial dependence and creates the 'Dutch Disease', meaning that local currencies appreciate against the us dollar, pushing down the price of imports and dampening industrial exports. This replicates the logic of dependence and the subordinated status of emerging countries on the global economic and geopolitical stage (Gudynas, 2011).

It is necessary to distinguish between two types of 'extractivism'. The first originates in the mining and energy sectors and comprises precious metals, oil, gas and mineral exploitation, which are earmarked primarily for export (Figure 12.1). The second is generated in the agriculture sector and comprises large monocrop plantations, which are usually managed by big companies (Ornelas, 2016).

Products such as soybean, palm oil, cereals and bananas usually fall into this latter category given that they are produced on a large scale with high levels of technology and for export purposes (Figure 12.2). Agricultural extractivism progressively co-opts land and resources in this sector, which reduces

circuits - the modern export circuit and a circuit that lags behind, characterised by low levels of technology, capital, and productivity, such as is the case in Colombia and Peru. 


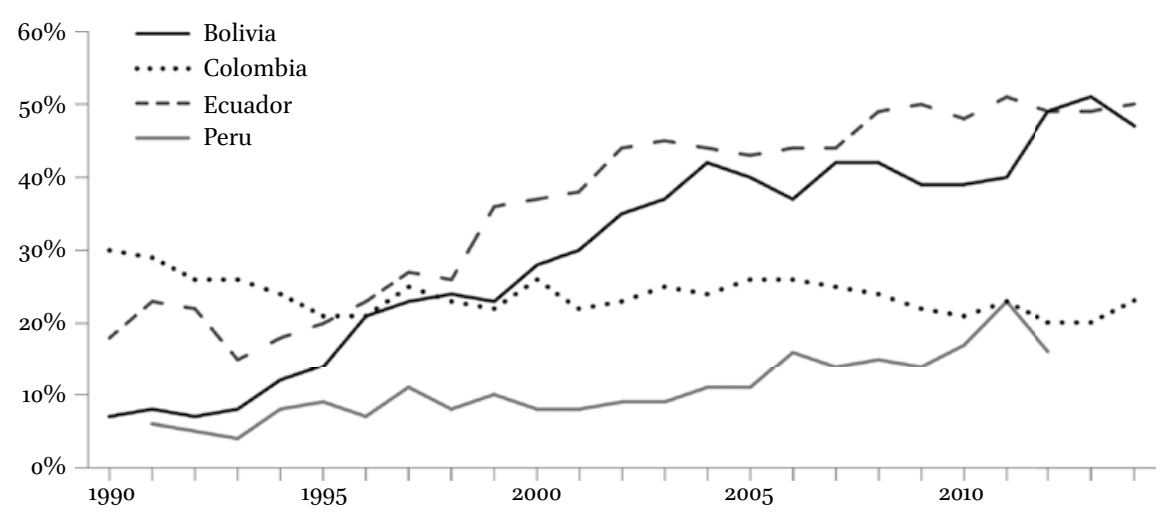

FIGURE 12.2 Main extractivist agricultural exports as a percentage of agriculture production, 1990-2014.

SOURCE: AUTHORS, WITH DATA FROM UN COMTRADE AND THE WORLD BANK.

the possibility of food for local consumption. In this scenario, countries are forced to import food provisions. When the raw material cycle is depressed, local currencies devaluate, the inflation rate jumps, and basic foodstuffs become more expensive given that local farmers are unable to supply the internal market. The economic recession is thus accompanied by inflation, also known as stagflation.

Agricultural exports are not all extractive in nature and it is not possible to define, in absolute terms, the weight of extractivist products in agricultural exports. As a precaution, we have used a handful of clearly extractive products for each country, and have compared them with the aggregate value of the agricultural sector. The products selected in the case of Bolivia are soybean and its derivatives, cereals, and Brazil nuts. For Colombia, we look at coffee, flowers, bananas and palm oil and, in the case of Ecuador, we opt for bananas, flowers, cacao, coffee and palm oil. For Peru, our selection is coffee, grapes and other fruits as well as canned vegetables.

In Latin America, extractivism has coincided with three other processes, which may be complementary in some cases and exclusionary in others. First, in the 1990s, dictatorial political systems and restricted democracy systems gave way to the restoration of liberal democracy and to audacious processes of decentralisation of political systems and public administrations, in particular the decentralisation of basic social policies (Restrepo, 2015). Second, almost five hundred years after the beginning of the conquest and colonisation of Latin America, ethnic communities achieved recognition of their right to exist as a people with their own rights, systems of justice, languages, authorities 
and forms of management (Comisión Verdad Histórica y Nuevo Trato con los Pueblos Indígenas, 2003). Lastly, nature is no longer seen as a source of unlimited resources and there is increasing awareness of the depletion of these riches. Measures have been implemented to determine the environmental cost of human activities and protected areas have been created in the form of parks, moorlands and natural sanctuaries (Gligo, 2001).

In this chapter, we explore the relationship between extractivism and the three above-mentioned processes in four countries- two of which, Colombia and Peru, are recognised adherents to neo-liberalism and the free market, while the other two, Bolivia and Ecuador, apply policies that are based on so-called 'twenty-first century socialism'.

In Bolivia, the neo-liberal model was abandoned after Evo Morales took office in January 2006. The Bolivian president based his state policy on a discourse that exalted the concept of buen vivir, ' 'indigenism', nationalism and anti-imperialism.

The concept of buen vivir originates from different South American indigenous peoples. There are varying interpretations of its meaning and implications. ${ }^{3}$ Despite differences, the concept is usually publicised as an ideology that opposes the liberal conception of the state and modern ideals of development (Vanhults, 2015).

Although it is not easy to define buen vivir, it is possible to work with the definition provided by Gudynas and Acosta, for whom buen vivir represents an 'opportunity to build another society based on man's coexistence in diversity and in harmony with nature based on the recognition of the fact that different cultural values exist in every country and throughout the world' (Gudynas and Acosta, 2011, 103).

Buen vivir is postulated as an alternative to capitalistic development that must be based on a new relationship with nature and the search for an economic model that does not plunder nature's resources. Thus extractivism does not fit into this alternative for development unless it is used transitorily as a tool for achieving said alternative development.

2 Also referred to, in certain contexts, as vivir bien and translated into English as 'Good Living'.

3 A vast compilation of the meanings of buen vivir for indigenous South Americans can be found in Huanacuni (2010). 
In Bolivia, this ideology is reflected in the 'Carta Magna' of 2009, which characterises the state as 'plurinational' while calling attention to the need to 'industrialise productive development of natural resources' as a means of eliminating social and economic poverty (Solón, 2014, our transl.).

The nationalist and 'indigenist' discourse of Bolivian president Evo Morales has generated a major debate because some believe it is merely rhetorical and did not translate into any significant change in the Bolivian state's policies (Rocha, 2015).

This anti-imperialist and anti-capitalist rhetoric contrasts with various initiatives in favour of 'reforming the Bolivian State and building a "modern" capitalist society without breaking relations of dependence and subordination to imperialism' (Rocha, 2015, x). In fact, President Morales passed the Law to Promote Investments in April 2014, which seeks to facilitate direct foreign investment flows.

In the case of Ecuador, the discourse of President Rafael Correa is very similar to that of his Bolivian counterpart, the state's policy being based on the concept of buen vivir (Leon, 2008). In addition, the constitution of 2008 establishes a plurinational conception of the state. It also posits that the exploitation of natural resources is necessary in order to achieve a more modern and equal society.

The national development plans of both countries share several objectives: reducing primary exports, increasing exports, increasing productivity and industrialisation, and strengthening the 'role of the state as a promoter of development' (Solon, 2014, our transl.).

One of the most important differences has to do with the redistributive discourse of Rafael Correa, who considers himself a Marxist and socialist and as such focuses on the working class. In his own words, his discourse is based on generating 'better labour policies, better wage policies, wage increases, democratisation of the ownership of capital, but... with a good system of redistributive taxes' (Paz and Cepeda, 2015, 2, our transl.).

In short, in their discourses, both countries prioritise protecting the environment and seeking out an alternative model of development, which is considered a means by which to achieve buen vivir.

On the contrary, Peru and Colombia have adhered to liberal discourses that give precedence to economic openness and the free market over state interventionism.

Currently Peru has free trade agreements (FTAs) with 20 countries and multilateral organisations (Peru, 2015), the most noteworthy of which are the FTAS with the United States, China, and the European Union. Peru is also currently in the process of negotiating or signing eight more FTAs. There are 12 FTAs in 
effect in Colombia (Colombia, 2015), including those with the United States and the European Union, and another eight agreements have been signed or are being negotiated. It is important to note that both countries are part of the Pacific Alliance agreement, which is being fine-tuned but seeks, among other aims, to ensure that the countries of the Alliance-Mexico, Chile, Colombia and Peru — can jointly negotiate trade agreements with countries in Asia-Pacific, the latter expected to be driving global growth in coming decades.

Both Colombia and Peru follow an economic policy that prioritises macroeconomic stability over industrialisation. It focuses on maintaining low rates of inflation, balanced public finances and free movement of capital and goods. In this scenario, industrial policy is reduced to contemplating only those actions that can generate an increase in the country's competitiveness, such as investment in infrastructure, administrative simplification, and lower taxes, all of which are meant to attract foreign investment.

In sum, both countries have based their discourse on free trade and foreign investments as the main mechanisms for promoting economic development. They explicitly place extractive activities involving raw materials at the forefront of these mechanisms because these ventures are constitutive of the comparative advantage that Ecuador and Colombia have over other underdeveloped countries in the realm of global trade.

3

\section{Convergent Trajectories?}

\subsection{Extractivism}

Despite the differences in discourse, all four countries have based their economic growth on extractive sectors. Based on the behaviour of mining and energy exports, it is possible to distinguish three phases that characterise the development of the extractive economy over the past twenty-five years in the four countries (Figure 12.3).

First came the contractive phase, which covered a large portion of the 199os, during which exports became less important due to weak international prices. Next was an expansive phase, which began in 1998 and picked up speed in 2003 due to the commodities boom. Last, we observe a stagnation phase, which threatened to plunge all countries dependent on primary exports, on oil in particular, into the depths of an economic crisis when the price of oil dropped from USD 150 per barrel to less than USD 40 per barrel in just two years.

Although the presence of the extractivist model has deepened in all four countries, there are major differences in the way the model is applied and the consequences it generates. It is possible to draw two typologies in order 


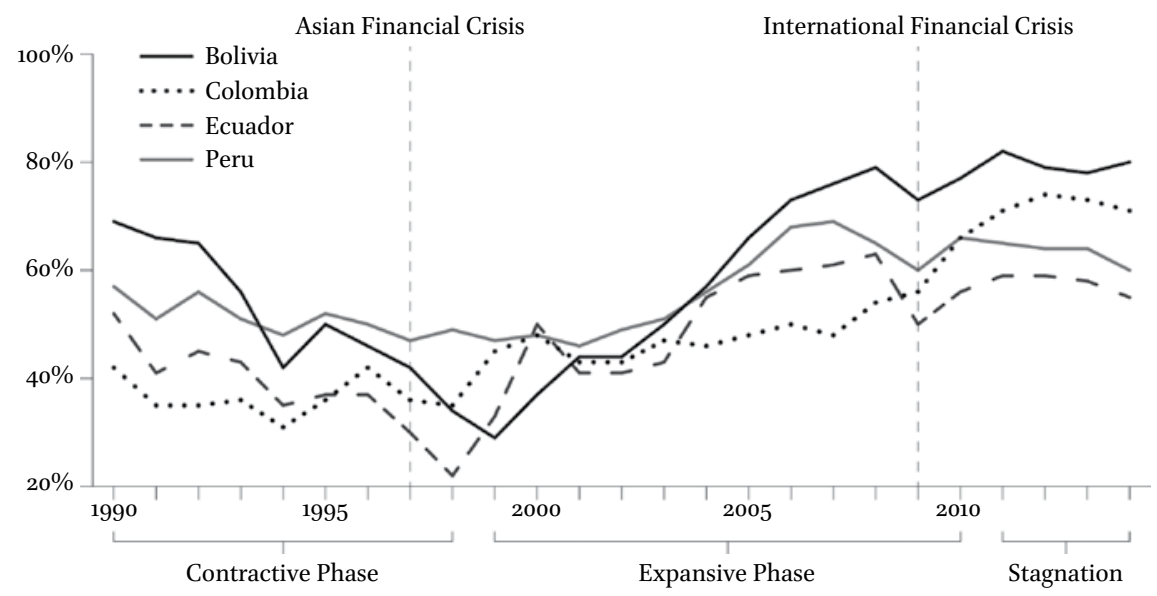

FIGURE 12.3 Exports of mining products and energy as a percentage of total exports,

1990-2014.

SOURCE: AUTHORS, WITH DATA FROM UN COMTRADE.

to clearly identify these differences. Colombia and Peru are part of a set of countries that assume an 'adaptive strategy' when faced with the opportunity of utilising commodities, meaning that they give in to the temptation of obtaining quick resources through large-scale efforts to exploit primary goods. This stimulates direct foreign investment, which in turn benefits the country by generating taxes and state investments, primarily in infrastructure and security. This approach is accompanied by a quest to develop national productive chains around primary activities while using surpluses to finance social and territorial policies, as well as science and technology. Ecuador and Bolivia, in contrast, follow a 'neo-developmentalist strategy'. They take advantage of booms in primary exports but implement compensatory policies to protect the internal market, diversify production, and generate added value in other economic sectors. Additionally, these policies seek to strengthen state ownership of large extractive companies and tax foreign companies in a way that favours the state. Neo-developmentalism assumes the paradigm of productive development as its main purpose, but it seeks to innovate the model with policies of social, ethnic and territorial equity, and with defending national interests against 'imperialism'.

Despite these differences, the results have been the same in all four countries, given that all of them have deepened their dependence on raw materials while their industries and agriculture have weakened against extractive sector interests. Additionally, all four countries remain in a position of subordination in the international division of labour, meaning that they export mainly low 
added value products (i.e. raw materials) and import high added value products (i.e. technology and capital).

In terms of exploitation-a key difference between the typologies-it is necessary to remember that state companies are not necessarily more efficient, nor do they cause less contamination when extracting natural resources. National private companies and transnationals are not necessarily more predatory than state-owned companies.

Portillo Riascos $(2014,2015)$ conducts a comparative analysis of the oil extraction models in Ecuador and Colombia, two countries that are ideologically distinct but which have the same degree of dependence on exports of crude. The author finds that the most significant difference between the two relates to the ownership of crude oil. In Ecuador, crude is owned by the state whereas, in Colombia, an extractive company can own the commodity. Hence, in Ecuador, national companies and transnationals are contractors working for the state, which hires their extraction services at a predetermined price. By contrast, in Colombia the state offers private companies oil well concessions, and focuses on regulating the sector's activities. National companies and transnationals, after having extracted resources and paid the corresponding taxes, are free to use these resources and to commercialise them. The state is also a majority shareholder in Ecopetrol, Colombia's main oil company.

According to the same author (Portillo Riascos, 2014, 2015), Ecuador has proven oil reserves of approximately 8.2 thousand million barrels while Colombia has reserves equivalent to only 2.2 thousand million barrels. Nevertheless, Colombia has considerably increased its production levels under the concessions model and, in the year 2012, it produced 944 million barrels a day on average, 60 per cent of which was generated by the state-owned company Ecopetrol. In contrast, Ecuador produces 505 thousand barrels a day on average. This situation shows that, in this case, the 'neo-extractivist' model, which is led by the state (a major shareholder in this business and its profits), is less efficient when it comes to exploiting natural resources than the 'adaptive model', which promotes the rights of transnational businesses to share in profits while being subject to low taxes.

A study conducted by Portillo Riascos strives to measure the profitability of oil in each country. The conclusion is that Ecuador captures a higher proportion of resources from the oil sector. The author's calculations show that the state in Ecuador reaped 53.2 per cent of oil revenues in 2012 while the state's share in Colombia was only 35.4 per cent in the same year. This suggests that neo-extractivist states obtain a larger proportion of revenues than that obtained by adaptive states. 


\subsection{Decentralisation}

Different degrees of political and fiscal decentralisation determine whether local governments block or facilitate advances in the extractive economy. In a country with advanced decentralisation processes, it would be logical to expect that royalties would be ceded to territorial bodies, which must deal with the socio-economic and environmental impacts generated by natural resource extraction. Territories should have the right to decide on land use, which implies determining if they want natural resource exploitation in their jurisdictions or not.

Decentralisation processes have been complex and have arisen in a broad range of circumstances. In Colombia, for example, decentralisation began with Legislative Act 01 of 1986, which reformed the National Constitution in order to allow mayors to be elected by popular vote. Subsequently, the 'Carta Magna' of 1991 stipulated that governors could be elected by the people, which led to a significant level of political autonomy at the local level. In contrast, fiscal autonomy has always been scarce given that numerous national laws convert local authorities into administrative and fiscal agents of the national government and the Congress of the Republic. Additionally, in 2002 and 2008, large percentages of economic transfers to territorial bodies were cut but political powers continued to be decentralised.

In the Bolivian case, decentralisation began in 1994 with Law No. 1551 for Citizen Participation, which gave political autonomy to the municipalities but failed to do the same with the prefectures, or governances, which continued to be controlled by the central government and benefited from little real effort to ensure administrative and fiscal decentralisation. This meant that these local government instances were highly subordinated to the national government and subject to its oversight. After massive and persistent manifestations in favour of departmental autonomy, political decentralisation was finally implemented in 2005. Governors, formerly nominated by the President, have since then been elected by local constituencies.

In Peru, decentralisation began in 2002 with Law No. 27783, the Law for the Bases of Decentralisation. Since then, the country has rolled out an accelerated process to transfer large amounts of resources and responsibilities to territorial entities. Nonetheless, the process is still incomplete given that fiscal autonomy has yet to be fully implemented and the central government continues to make decisions regarding the use of resources.

In Ecuador, decentralisation was first adopted in 1977, and it was strengthened through the constitution of 1979. Yet the decentralisation process was not implemented in earnest until 2008, when implementation efforts were 
stepped up. Decentralisation was further reinforced in 2010 with the adoption of the Organic Code of Territorial Ordering.

In all four countries, only a fraction of the total royalties received from mining and oil exploitation are allotted to the territorial bodies where extractive activities take place. These payments are meant to be compensation for economic, social and environmental damage. In Peru, the government also cedes $5^{0}$ per cent of the income tax paid by extractive companies to the regions.

The distribution of state revenues from the mining and energy sectors among the different levels of government (including national, regional, departmental and municipal levels) differs significantly among the countries studied (Table 12.1). In Ecuador, the percentage ceded to the territories is very low and practically insignificant. By comparison in Peru, the percentage ceded is very considerable given that it represents 50 per cent of total revenues; nevertheless, territorial governments must invest these resources in infrastructure and its maintenance, which reduces the freedom to allot them.

Neither of these countries have a mechanism for sharing a percentage of this income with non-producing municipalities and departments. If a mechanism were in place, it would generate a principle of solidarity with poor or marginalised regions. The lack of inter-regional solidarity is dramatic in Peru, where six departments of the country's 26 account for 64 per cent of the resources obtained from mining while four departments represent 99 per cent of the money received from oil.

By contrast, in Bolivia and Colombia the central governments cede a considerable portion of taxes to the regions and there are fewer 'ties that bind' in the central government's budget; thus, these resources belong to the regions. In both countries, there is a mechanism of solidarity with non-producing regions, which generates a principle of inter-regional solidarity and provides

TABLE 12.1 Decentralised entities' shares of state resources obtained from the mining and energy sectors

\begin{tabular}{lcc}
\hline Country & $\mathbf{2 0 0 7 - 2 0 0 9}$ & $\mathbf{2 0 1 0 - 2 0 1 2}$ \\
\hline Ecuador & $2.28 \%$ & $\mathbf{1 . 2 7 \%}$ \\
Colombia & $33 \cdot 73 \%$ & $35.60 \%$ \\
Bolivia & $40.97 \%$ & $39.31 \%$ \\
Peru & $47.66 \%$ & $49 \cdot 34 \%$ \\
\hline
\end{tabular}

SOURCE: ECLAC (2014a). 
some resources to marginalised regions. Both countries have also recently undertaken fiscal re-centralisation processes for resources issuing from royalties, but have used very different mechanisms.

In Bolivia, a reform for distributing the Direct Tax on Hydrocarbons (Impuesto Directo a los Hidrocaburos, IDH) was approved in $2007,{ }^{4}$ obligating regions to cede 30 per cent of this tax to finance the 'Dignified Income' programme - a highly popular central government initiative that provides a monthly stipend to adults over the age of sixty (Yanguas, 2013).

In Colombia, re-centralisation began with Legislative Act 05 of July 18, 2011, which reinforced the solidarity mechanism with non-producing regions at the same time that various investment funds were being set up to receive royalty resources. Of the more noteworthy funds, one concentrates the royalties in producer regions, another distributes royalties in all the country's municipalities and another is used for investment in science and technology projects. Resources from royalties continue to belong to the regions, but this money is funnelled into the funds created in 2011, which means that the regions do not have free access to these resources. The decision to allot resources from these funds is made by a collegiate body known as the Collegiate Bodies of Administration and Decision Making (OCAD), which is formed by delegates of municipalities and departments but also from the central government.

In conclusion, there are three different scenarios in the countries studied. In Ecuador, the degree of centralisation continues to be very firm and is reflected in the low level of distribution of state mining and energy revenues. In Peru, fiscal decentralisation of resources in the mining and energy sectors contrast with the fact that these activities are concentrated in only a few departments. Colombia and Bolivia are bogged down by long economic and political decentralisation processes, which are reflected in the large quantity of resources from the extractive sector that are ceded to all of the regions, including those that are non-producing. Nonetheless, re-centralisation processes are underway in both countries.

In sum, the differences that exist are not between 'neo-liberal' and 'socialist' approaches, but are instead between political processes and social mobilisations that spill over into deep processes of decentralisation in Colombia and Bolivia, unlike in the more centralised political systems of Ecuador and Peru.

4 The IDH, created in 2005, levies a tax of 32 per cent on hydrocarbons, in addition to 18 per cent of previously existing royalties. 


\subsection{Ethnic Rights}

The right to conduct prior popular consultation and to defend communal property, as well as the right to preserve traditions, are all noteworthy. All four countries are widely recognised for the levels of legal respect they show for ethnic rights.

According to Yrigoyen (2011), it is possible to identify three cycles of legal and political reforms that aim to promote ethnic rights in the Latin American region. The first cycle began with the approval of Convention 169 of the International Labour Organization (ILO), which enshrines these rights and obligates signatory countries to enforce these rights. In the Colombian and Bolivian cases the convention was approved in 1991, while in Peru and Ecuador the necessary agreements were signed in 1994 and 1998, respectively.

The second cycle of reforms incorporates ethnic rights into the constitution of each country - particularly the 'political rights to participation, consultation and autonomy as well as over their [own] lands, territories, [and] natural resources and those relative to linguistic and cultural matters' (Aylwin, 2014). Ethnic rights were introduced into the Colombian constitution in 1991, the Peruvian constitution in 1993, the Bolivian constitution in 1994, and the Ecuadorian constitution in 1998.

The last cycle of reforms refers to what Yrigoyen (2011) calls 'plurinational constitutionalism'. This change implies recognising the existence of different peoples within the same state, which makes it necessary to speak of a 'plurinational state' while organising a structure that fully contemplates this reality. The only states that have been declared plurinational are Ecuador and Bolivia, which introduced these changes into their new political constitutions in 2008 and 2009, respectively. The 'socialism' practiced in these countries has been innovated to recognise the nation's ethnic and cultural pluralisms, which have been integrated into important regulatory, institutional and political developments.

Nevertheless, legal recognition and political reality are often considered distant relations, as is frequently the case in the countries studied, in particular when ethnic rights have blocked the way of mining and oil exploitation. On many occasions communities have opposed extractivism on their lands. When prior consultations are required by law, communities have often requested that extractive activities would not be conducted in their territories. Nevertheless, as consultation is not binding, authorities, along with the extractive companies, disregard the opinions of indigenous peoples and continue their projects.

An emblematic example is the Supreme Decree No. 2298 issued by the Morales government in Bolivia, which stipulates that consultation with communities should last no more than 45 days after a private company opens 
a consultation process, after which the private company can forgo the consultation process even if the communities have failed to respond within the 45-day period. This constitutes a grave abuse of the right of ethnic peoples, and represents a major contradiction in the national policy-a policy that is the president's response to the need to increase gas production to offset falling international prices.

In Ecuador, Bolivia and Peru, indigenous peoples constitute powerful social movements that have the capacity to exercise a decisive influence on the political scene. In Ecuador, President Correa was elected thanks in large part to the support of the Confederation of Indigenous Nationalities of Ecuador (Confederación de Nacionalidades Indígenas del Ecuador, CONAIE), which is the most important social movement in the country. At the beginning of his mandate, Correa took up indigenous causes by endorsing "anti-imperialist preaching", a negative attitude toward free trade agreements, and the defence of natural resources' (El Comercio, 2015). Later, he progressively distanced himself from the social movements, notably indigenous ones that brought him to power in 2006. He first turned his back on CONAIE after the 2006 elections. And after the new constitution was adopted in 2008, he proceeded to do the same with other organisations, including the National Confederation of Peasant, Indigenous and Black Organizations (Confederación Nacional de Organisaciones Campesinas, Indígenas y Negras, FENOCIN). ${ }^{5}$ This process has created a significant rift between the government and social movements, which has led to various protests and subsequent repression by the military. One of the most important reasons for this division was the move by Correa's government to rapidly exploit natural resources, which have become an important source of financing.

Along similar lines, Bolivian president Evo Morales, who is from the Aymara community, was elected with the support of indigenous movements and distanced himself from the largest indigenous movements after his election. However, in contrast with what happened in Ecuador, some indigenous individuals were nonetheless appointed in the central government in Bolivia. Disagreement was bound to arise between the government and social movements, including the Confederation of Indigenous Peoples of Bolivia (Confederación de Pueblos Indígenas de Bolivia, СID ОB), which is the largest social movement in the country, the Guarani Indians, and the National Council of Ayllus and Markas of Qullasuya (Consejo Nacional de Ayllus y Markas del Qullasuyu, CONAMAQ) among others. Relations with a government that proclaims itself 'anti-imperialist' but follows 'extractive' activities, claims to be 'indigenist' but

5 For a more detailed description, see Gómez (2015) and Trujillo (2010). 
deepens a 'developmentalist' system that contradicts certain ethnic ideals, have generated tensions and divisions in some social movements. On several occasions, some movements have supported the president and more than one have backed his party, the Movement Toward Socialism (Movimiento al Socialismo, MAS), but this has yet to put the brakes on a convergence of social movements that are discontented with policies and the president's centralist style of government.

Once again, the main disagreement is with the extractivist model of President Morales, who depends a great deal on natural resources, especially gas extraction, to finance various social programmes (Zeballos and Urbina, 2015).

Both President Morales and President Correa managed to maintain high level of popularity, which was over 60 per cent in the years prior to the decline in commodity prices. This was due, to a large extent, to major investment in social policies that have contributed to significantly reducing poverty levels (Fig. 12.4). This allowed both presidents to distance themselves from social movements, since the two presidencies orchestrated a culture of selection in the allocation of projects, investments and syndications, by favouring certain social movements and organisations while excluding and persecuting others.

In Peru, the situation is not very different from that in the two countries already discussed, given that President Ollanta Humala was also victoriousin the elections of 2011 - due, to a large extent, to the support of indigenous and peasant groups. Humala promised a 'great transformation', which implied abandoning neo-liberalism and defending the population from the interest of multinational companies, among other points. But after his election Humala

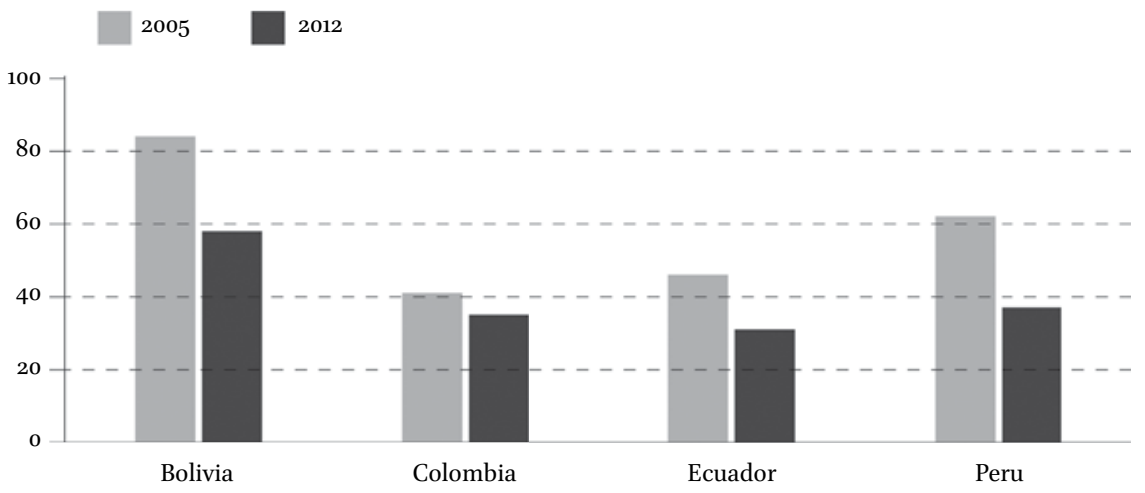

FIGURE 12.4 Multi-dimensional poverty. Selected countries in terms of the percentage of the total population-2005 and 2012.

SOURCE: AUTHORS, WITH DATA FROM ECLAC (2014b). 
opted to continue, and actually deepen, the neo-liberal model and extractivist practices (Garra, 2014). As in Bolivia and Ecuador, prior consultation has become, in practice, exceptional; and, when it happens, it is consultative rather than regular and binding.

The case of Colombia is different because of the ongoing internal conflict. The dilemma between continuing the war or attempting a peace process has been a definitive factor in each Colombian presidential elections since the 1970s. For this reason, social and ethnic movements have not had the same weight in electoral victories, in the formation of governments, and in the formulations of public policies, as it is the case in Ecuador and Bolivia. Álvaro Uribe won the elections of 2002 and 2006 by promising a no-truce confrontation with guerillas. Juan Manuel Santos won in 2010 with the promise that he would continue on the path of war, but abandoned this commitment in exchange for a peace process that led to his re-election in 2014. During this lapse of time the indigenous struggle became stronger, despite official and guerilla violence against ethnic autonomy. Nevertheless, the victories have been more symbolic and cultural. Thus, as public support for ethnic demands grows, the government makes agreements and promises investment that it generally fails to deliver on, triggering subsequent mobilisations (Vieira, 2012; ONIC, 2013; Bermúdez, 2014). Prior consultation began merely as a random exercise to gather information while promising compensation for extractive intervention in ethnic territories. Subsequently, the Constitutional Court deemed that consultation processes were obligatory and binding, which spurred the government to roll out a media and legal campaign against the 'enemies of development', reminding the people that if the nation owns the subsoil, no community could legally oppose extractive decisions that were legalised at the central level.

In sum, the four countries studied converge towards legal recognition of the rights of ethnic minorities. At the same time, all four countries demonstrate disdain for these rights, at the institutional level and in their central governments in particular, which see prior consultation as an impediment to extractivist economic development.

\subsection{The Environment}

All of the countries studied have implemented important processes to protect the environment within the framework of a burgeoning environmental awareness that has led states to progressively commit to environmental protection as companies and consumers demonstrate more interest in the issue. The four countries signed the Paris Agreement of 2015, the Kyoto Protocol of 1998, and a dozen other agreements that commit them to protecting the environment 


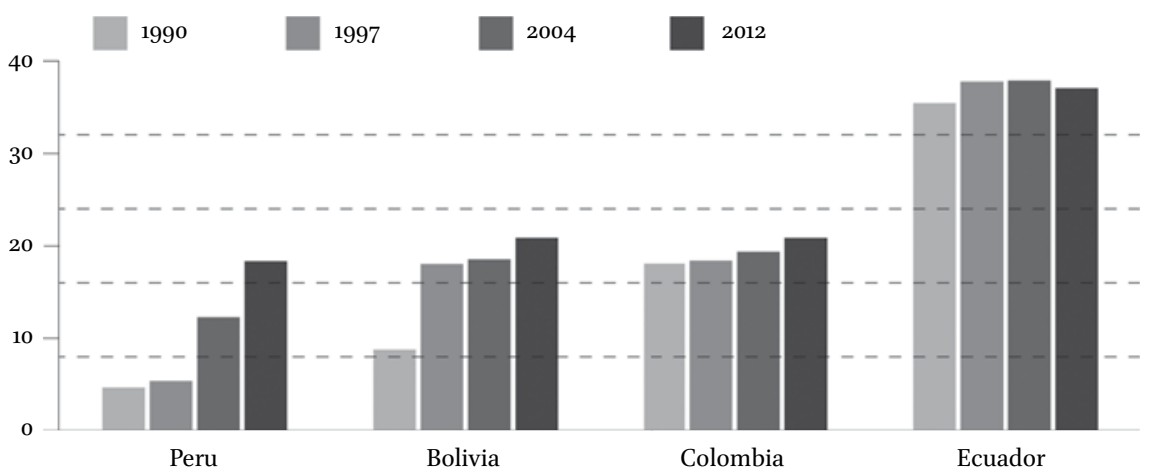

FIGURE 12.5 Protected land and ocean areas as a percentage of total territory. SOURCE: WORLD BANK.

and modifying national regulations and institutions to align with international commitments.

One of the events that arose from this process was the decision to create ministries of the environment-a step that generates a stronger institutional presence in environmental matters and reflects greater political awareness with regard to these issues. In Colombia, for example, the Ministry of the Environment and Sustainable Development was created in 1993 through Law 99 for the Environment, while in Ecuador the Ministry of the Environment was created in 1996 through Executive Decree No. 195. Subsequently, in 2008, the Ministry of the Environment of Peru was created through Legislative Decree No.1013, and lastly, in 2009, the Ministry of the Environment and Water was created in Bolivia through Presidential Supreme Decree No. 29894.

This process has also led to an expansion of the numbers and the extent of natural reserves in the countries studied (Figure 12.5). These reserves constitute major progress on the environmental front given that no harmful activities can be conducted within them, including - for example-natural resource extraction.

In the last few decades, Peru and Bolivia have made astounding progress in their efforts to expand the protected areas of their countries, growing the total area concerned fourfold and threefold, respectively, to reach levels of around 20 per cent of total territory in each case. Nevertheless, both countries stand out due to the low proportion of protected areas in their territories. The situation in Colombia and Ecuador is different given that both countries have a long history of maintaining large reserves. This explains why these countries have not significantly expanded their reserves in the last few years. In fact, Ecuador has posted a decline in total protected areas under Correa's government. 


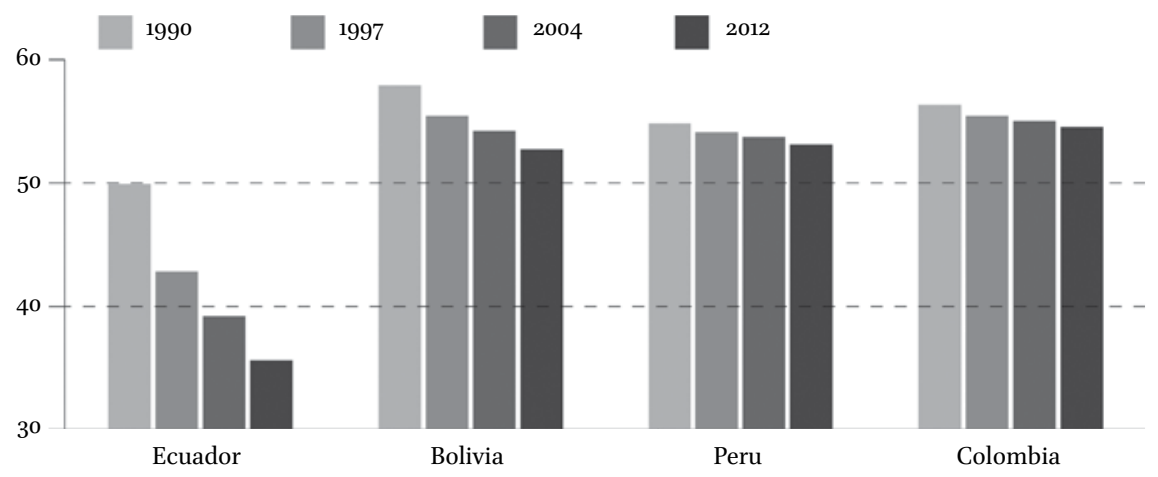

FIGURE 12.6 Territory covered by forests as a percentage of national territory, 1990-2010. SOURCE: ANDEAN COMMUNITY OF NATIONS (ACN).

Despite institutional efforts, deforestation has not ceased in any of these countries. The proportion of forested land has declined dramatically in Ecuador, which has lost approximately one-third of such areas over the last 20 years. Although less forested area has been lost in Bolivia, Peru and Colombia, the fact that the process has not slowed or stopped is of particular concern (Figure 12.6).

Progress towards protecting the environment has clashed with extractivism, whose importance in the economy has grown, creating tensions and irreconcilable disputes given that each of the countries' central governments are avidly promoting mining and energy extraction to generate more resources with which to finance the social policies they need to implement to maintain popular support.

In every case, the national government is in charge of expediting permits for exploitation and it also issues environmental permits, which puts its various objectives at odds with one another given that reducing the procedures and requirements, or indeed the actual need, for in-depth technical, environmental studies may generate major economic and fiscal benefits at the cost of environmental goals.

Governments can choose to disregard institutional precedents by authorising, for example, the exploration and exploitation of natural reserves, as was recently the case in Bolivia, where President Morales, driven by his mission to increase gas reserves, gave the green light (through Supreme Decree No.2366) to exploration in 11 of 22 protected areas of the country (Zeballos and Urbina, 2015).

In Ecuador, President Correa has gone against all odds to authorise oil exploitation in the Yasuni National Park, which is one of the world's most biodiverse areas (Wilkinson, 2015). 
TABLE 12.2 Exports from the national energy base as a percentage of total energy production

\begin{tabular}{lllll}
\hline Year & Colombia & Bolivia & Ecuador & Peru \\
\hline 2001 & $63 \%$ & $49 \%$ & $65 \%$ & $29 \%$ \\
2005 & $65 \%$ & $65 \%$ & $70 \%$ & $32 \%$ \\
2009 & $69 \%$ & $62 \%$ & $69 \%$ & $28 \%$ \\
2013 & $80 \%$ & $67 \%$ & $71 \%$ & $54 \%$ \\
\hline
\end{tabular}

SOURCE: INTERNATIONAL ENERGY AGENCY.

There are no significant examples of legal exploitation in the natural parks of Colombia and Peru. Nonetheless, numerous mining and energy projects have been set up in the jungle, in the Amazon jungle in particular. Dourojeanni et al. (2009) show that Peru has a total of 138 mining concessions operating in the Amazon basin. In Colombia, the government intends to step up mining exploitation in the Amazon by creating 'strategic mining areas' that will allow the government to offer 20 million hectares in concessions to large mining companies, although this process has been temporarily delayed by a court ruling (El Tiempo, 2015). To legally back its extractives strategy, the second Santos government (2014-) created 'express permits', a process which reduces the time needed to issue permits from two years and four months to only 100 days-weakening environmental oversight and prior consultation processes in the process.

Both groups of countries, neo-liberal and socialist, not only export the majority of their gross energy production (oil, gas, coal and biofuels) but have posted an upwards trend with regard to such exports in the last few years (Table 12.2). This also indicates that the primary extractive and dependent economy has grown while industrial bases have failed to expand.

\section{$4 \quad$ Conclusion}

Throughout this chapter we have discussed the fact that ideological discourse and orientation are not the only elements that determine the political reality and the direction of state policies in the countries studied. Mutually antagonistic, 'neo-liberal' and 'socialist' discourses are converging towards greater dependence on the mining and energy sectors, which leads to deindustrialisation and 'deagrarianisation'. With the resources generated through the expansion of this model, social policies geared towards policy reduction have 
enabled the indicator of unmet basic needs (UBNS) to drop, thus legitimising government policies, whether neo-liberal or socialist.

Another characteristic shared by these countries is that they all recognised ethnic rights in the 1990s. Yet this process met with a sharp decline in the year 2000 when the four governments decided to apply restrictions on prior consultation, one of the main rights granted to indigenous communities against extractive companies, because the latter consider consultation processes burdensome.

The countries also share varying degrees of similarity in terms of the damage they cause to the environment, and to the Amazon jungle in particular, in order to drive the extractive economy.

The countries differ, however, in terms of other facets that are not attributable to neo-liberal and socialist distinctions. This is the case of decentralisation. In neo-liberal Colombia and socialist Bolivia, local governments receive a higher share of the resources generated by the exploitation of non-renewable resources and enjoy a certain degree of autonomy with regard to deciding how these resources are used. By contrast, in socialist Ecuador the central government owns the royalties and has no legal obligation to share them with decentralised authorities (i.e. the entidad territorial), while in neo-liberal Peru, vast decentralised resources are concentrated in a few regions and are allotted to very specific purposes.

A parting comment: the extractive temptation reinforces an ancestral characteristic of Latin American states-centralism and 'presidentialism', where national powers selectively dole out their social and economic interventions in regional territories in such a way as to reinforce inequalities in development capacity and the political power of different regional territories.

\section{References}

Aylwin, J. (2014) 'Los derechos de los pueblos indígenas en América Latina: Avances jurídicos y brechas de implementación', in J.F. Beltrão et al. (eds.) Derechos Humanos de los Grupos Vulnerables (Barcelona: Red de Derechos Humanos y Educación Superior), pp. 275-300, https://www.upf.edu/dhes-alfa/materiales/docs/DHGV _Manual.pdf (accessed on 21 September 2016).

Bermúdez, A. (2014) 'A buen resguardo la relación de Santos con los indígenas', La Silla Vacía, October 18, http://lasillavacia.com/historia/santos-le-cumple-sus-aliados -indigenas-48874 (accessed on 10 December 2015).

Colombia (Government of) (2015) Acuerdos comerciales y de inversión (Bogotá: Ministerio de Comercio, Industria y Comercio), http://www.tlc.gov.co/index.php (accessed on 15 January 2016). 
Comisión Verdad Histórica y Nuevo Trato con los Pueblos Indígenas (2003) 'Reconocimiento de los Derechos de los Pueblos Indígenas en el Derecho Internacional y Comparado', Informe de la Comisión Verdad Históricay Nuevos Trato con los Pueblos Indígenas, 2 (Santiago de Chile: Comisionado Presidencial para Asuntos Indígenas), pp. $113^{-131 .}$

Dourojeanni, M., A. Barandiarán and D. Dourojeanni (2009) Amazonía peruana en 2021. Explotación de recursos naturales e infraestructuras: ¿Que está pasado? ¿Que es lo que significan para el futuro? (Lima: ProNaturaleza ; SPDA; DAR; ICAA), http:// www.spda.org.pe/?wpfb_dl=48 (accessed on 21 September 2016).

ECLAC (United Nations Economic Commission for Latin America and the Caribbean) (2014a) Pactos para la igualdad. Hacia un futuro sostenible (Lima: ECLAC), http:// www.cepal.org/es/publicaciones/36692-pactos-la-igualdad-un-futuro-sostenible (accessed on 21 September 2016).

ECLAC (2014b) Panorama Social de América Latina 2014 (Santiago de Chile: ECLAC), http://www.cepal.org/es/publicaciones/37626-panorama-social-america-latina -2014 (accessed on 10 February 2017).

El Comercio (2015) 'Con el "levantamiento” contra Rafael Correa los indígenas buscan recuperar protagonismo político', El Comercio, 17 July, http://www.elcomercio.com/ actualidad/conaie-levantamiento-indigenas-paro-rafaelcorrea.html (accessed on 3 December 2015).

El Tiempo (2015) 'Suspenden provisionalmente normas de áreas estratégicas mineras. Por no realizar consulta previa a comunidades, resoluciones del Gobierno se quedaron sin efecto', El Tiempo, 20 May, http://www.eltiempo.com/politica/justicia/ consejo-de-estado-suspenden-provisionalmente-normas-de-areas-estrategicas -mineras/15789735 (accessed on 21 September 2016).

Garra, S. (2014) 'NANKI ACHIKTA! Una mirada a las resistencias indígenas al extractivismo en la Amazonía peruana' (Condorcanqui y Datem del Marañón), Alternativas para un Desarrollo Ecológico, Autodeterminado y Humano, 3 October, http://www .aldeah.org/es/nanki-achikta-una-mirada-las-resistencias-indigenas-al-extracti vismo-en-la-amazonia-peruana-condor-o (accessed on 9 December 2015).

Gligo, N. (2001) La dimensión ambiental en el desarrollo de América Latina (Santiago de Chile: ECLAC), http://www.cepal.org/es/publicaciones/2262-ladimension-ambiental-en-el-desarrollo-de-america-latina (accessed on 21 September 2016).

Gómez, C. (2015) 'La relación del gobierno de Alianza País presidido por Rafael Correa con las organizaciones indígenas ecuatorianas', Revista de Ciencia Política, 16, http://www.revcienciapolitica.com.ar/numı6art8.php (accessed on 21 September 2016).

Gudynas, E. (2011) La Maldición de los Recursos Naturales, 3 November (Montevideo: Semanario VOCES), http://www.gudynas.com/periodismo/GudynasMaldicion AbundanciaVocesNovi1F.pdf (accessed on 12 February 2016). 
Gudynas, E., and A. Acosta (2011) 'El buen vivir o la disolución de la idea de progreso', in M. Rojas (ed.) La medición del progreso y el bienestar. Propuestas desde América Latina (México: Foro Consultivo Científico y Tecnológico de México), pp. 103-110.

Huanacuni, F. (2010) Buen Vivir / Vivir Bien. Filosofía, políticas, estrategiasy experiencias regionales andinas (Lima: Coordinadora Andina de Organizaciones Indígenas).

León, M. (2008) El 'buen vivir': objetivo y camino para otro modelo (Paris: Institut de recherche et débat sur la gouvernance), http://www.institut-gouvernance.org/es/ analyse/fiche-analyse-46o.html (accessed on 15 January 2016).

ONIC (Organización Nacional Indígena de Colombia) (2013) Delegados Indígenas de la Mesa Permanente de Concertación Sientan Posición Frente al Gobierno de Juan Manuel Santos, 5 September, http://cms.onic.org.co/2013/og/delegados-indigenasde-la-mesa-permanente-de-concertacion-sientan-posicion-frente-al-gobierno-de -juan-manuel-santos/ (accessed on 11 December 2015).

Ornelas, J. (2016) 'Sociedades posneoliberales en América Latina y persistencia del extractivismo', Economía Informa, 396, pp. 84-95, DOI:10.1016/j.ecin.2016.01.005.

Paz, J. and M. Cepeda (2015) El 'Socialismo del siglo XXI' en Ecuador, Boletin del THETaller de Historia Económica (Quito: Facultad de Economía. Pontificia Universidad Católica del Ecuador), http://puce.the.pazymino.com/JPyMC-SOCIALISMO _SIGLO_XXI_ECUADOR.pdf (accessed on 5 December 2015).

Peru (Government of) (2015) Acuerdos Comerciales del Perú (Lima: Ministerio de Comercio Exterior u Turismo), http://www.acuerdoscomerciales.gob.pe/index .php?option $=$ com_content $\&$ view $=$ category\&layout $=$ blog $\&$ id $=36 \&$ Itemid $=27$ (accessed on 15 January 2016).

Portillo Riascos, L. (2015) 'Los modelos de explotación petrolera de Ecuador y Colombia: un análisis desde el extractivismo y el neoextractivismo (segunda parte)', Tendencias 16(2), pp. 13-35, http://revistas.udenar.edu.co/index.php/rtend/article/ view/2246/2642

Portillo Riascos, L. (2014) 'Los modelos de explotación petrolera de Ecuador y Colombia: un análisis desde el extractivismo y el neoextractivismo', Tendencias, 15(2), pp. 11-29, http://revistas.udenar.edu.co/index.php/rtend/article/view/2053 (accessed on 21 September 2016).

Restrepo Botero, D. (2015). Procesos de descentralización en Bolivia y Colombia, 19802005: Una propuesta de economía espacial comparada (Bogotá: Universidad Nacional de Colombia), http://web.uaemex.mx/pwww/rii/docs/Procesos\%2oBol_Col _OCTUBRE13.pdf (accessed on 20 September 2016).

Rocha, J. (2015) 'Evo Morales: ¿nacionalismo indígena en el poder?’ LIT-CI, 3 o August, http://litci.org/es/lit-ci-y-partidos/partidos/ls-bolivia/evo-morales-nacionalismo -indigena-en-el-poder/ (accessed on 15 December 2015).

Sánchez,D.(2006) 'Inserción externa, heterogeneidady globalización en AméricaLatina', Mimeo, http://pendientedemigracion.ucm.es/info/ec/jec1o/ponencias/715Sanchez Acochea.pdf (accessed on 12 January 2016). 
Solón, P. (2014) 'Apuntes para el Debate. Buen vivir / Vivir bien', Alternativas Sistémicas, 31 July, http://systemicalternatives.org/2014/07/31/apuntes-para-el-debate-buen -vivir-vivir-bien/ (accessed on 3 December 2015).

Trujillo, J.G. (2010) 'Las organizaciones indígenas y el gobierno de Rafael Correa', Íconos. Revista de Ciencias Sociales, 37, pp. 13-23, http://www.flacso.org.ec/docs/i37leon.pdf (accessed on 21 September 2016).

Vanhults, J. (2015) 'El laberinto de los discursos del Buen vivir: entre Sumak Kawsay y Socialismo del siglo XXI', POLIS, 40, http://polis.revues.org/10727 (accessed on 21 September 2016).

Vieira, C. (2012) 'Indígenas-Santos: el diálogo colombiano que no fue', Inter Press Service, 22 August, http://www.ipsnoticias.net/2012/o8/indigenas-santos-el-dialogo -colombiano-que-no-fue/ (accessed on 12 December 2015).

Wilkinson, D. (2015) Ambientalistas bajo acoso en Ecuador. Correa arremete contra el activismo ambientalista (New York: Human Rights Watch). https://www.hrw.org/es/ news/2015/og/o1/ambientalistas-bajo-acoso-en-ecuador (accessed on 22 November 2015).

Yanguas, J. (2013) 'Industrias extractivas, descentralización y desarrollo local: economía política de políticas fiscales y redistributivas en Perú y Bolivia', in R. Domínguez and S. Tezanos (eds.) Desafíos de los Estudios de Desarrollo: actas del I congreso Internacional de Estudios del Desarrollo (Santander: Red Española de Estudios del Desarrollo).

Yrigoyen, R. (2011) 'El horizonte del constitucionalismo pluralista: del multiculturalismo a la descolonización', in C. Rodríguez (ed.) El derecho en América Latina. Un mapa para el pensamiento jurídico del siglo XXI (Buenos Aires: Siglo XXI Editores), pp. 139-159.

Zabalo, P. and M. Zurbano (2011) Liberalización económica y desarrollo. Mitos y realidades de algunas economías emergentes (San Sebastián: Universidad del País Vasco), xiiirem.ehu.es/entry/content/208/cod_014.pdf (accessed on 12 January 2016).

Zeballos, M. and I. Urbina (2015) 'Bolivia sin fronteras al extractivismo: exploración en áreas naturales protegidas', Gran Angular, 4 August, http://elgranangular.com/blog/ reportaje/bolivia-sin-fronteras-al-extractivismo-exploracion-en-areas-naturales -protegidas/ (accessed on 12 December 2015). 